\title{
A tale of two tells: dating the Çatalhöyük West Mound
}

\author{
David Orton ${ }^{1, *}$, Jana Anvari ${ }^{2}$, Catriona Gibson ${ }^{3}$, Jonathan Last ${ }^{4}$, \\ Amy Bogaard ${ }^{5}$, Eva Rosenstock ${ }^{2} \&$ Peter F. Biehl $^{6}$
}

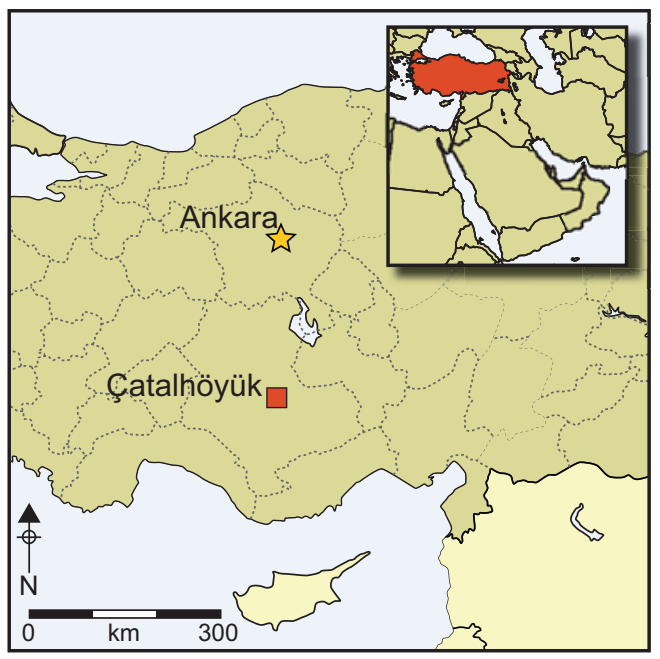

Çatalhöyük is one of the most well-known and important Neolithic/Chalcolithic sites in the Middle East. Settlement at the site encompasses two separate tell mounds known as Çatalhöyük East and West, with the focus of attention having traditionally been upon what is often regarded as the main site, the earlier East Mound. Limitations of dating evidence have, however, rendered the nature of the relationship between the settlements on these mounds unclear. Traditional models favoured a hiatus between their occupation, or, alternatively, a rapid shift from one site to the other, often invoking changes in natural conditions by way of an explanation. New dates challenge these theories, and indicate a potentially significant overlap between the occupation of the mounds, starting in the late seventh millennium $B C$.

Keywords: Turkey, Çatalhöyük, Neolithic, Chalcolithic, radiocarbon dating, tell settlement

\section{Introduction}

The Anatolian Neolithic tell (or Turkish höyük) settlement of Çatalhöyük was investigated by James Mellaart from 1961-1965, and by Ian Hodder and others from 1993-2017. Located on the Konya Plain, in central Turkey, Çatalhöyük is famed for densely packed houses,

\footnotetext{
BioArCh, Department of Archaeology, University of York, King's Manor, York YO1 7EP, UK

Institute of Prehistoric Archaeology, Freie Universität Berlin, Fabeckstraße 23-25, 14195 Berlin, Germany

Department of Archaeology, University of Reading, Whiteknights Box 227, Reading RG6 6AB, UK

Historic England, Fort Cumberland, Portsmouth P04 9LD, UK

Institute of Archaeology, University of Oxford, 36 Beaumont Street, Oxford OX1 2PG, UK

6 Department of Anthropology, University at Buffalo, 380 MFAC, Ellicott Complex, SUNY, Buffalo, NY 14261, USA

* Author for correspondence (Email: david.orton@york.ac.uk)
}

(C) Antiquity Publications Ltd, 2018. This is an Open Access article, distributed under the terms of the Creative Commons Attribution licence (http://creativecommons.org/licenses/by/4.0/), which permits unrestricted reuse, distribution and reproduction in any medium, provided the original work is properly cited.

ANTIQUITY 92363 (2018): 620-639

https://doi.org/10.15184/aqy.2018.91 


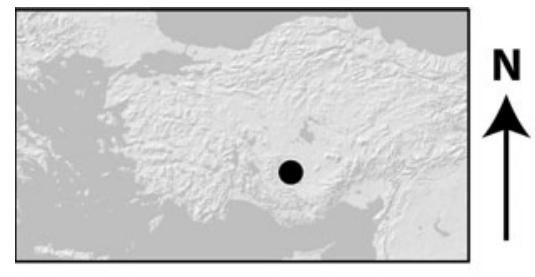

\section{West Mound}

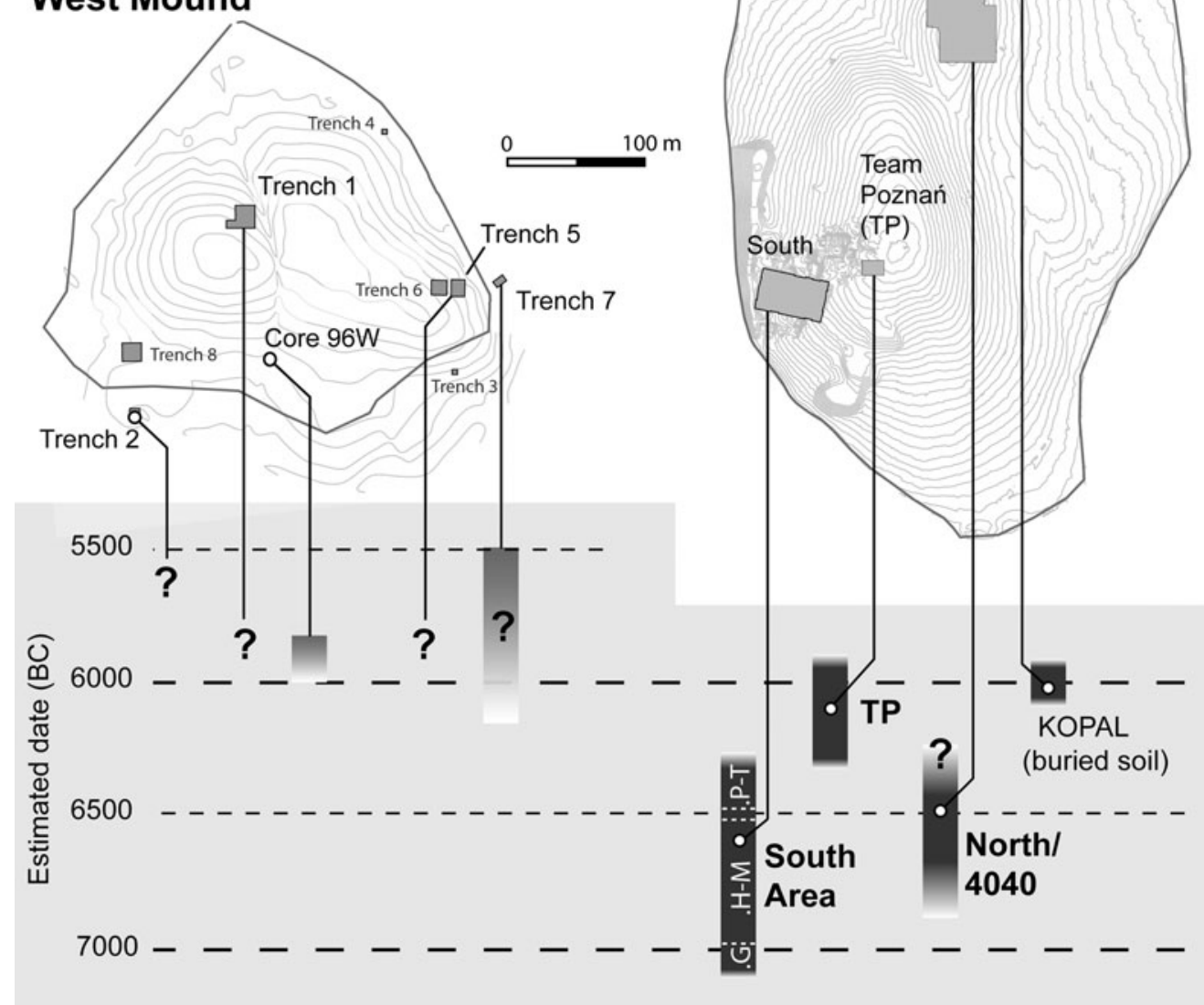

Figure 1. Çatalhöyük East and West, showing approximate previous dating estimates and uncertainty in the relationship between the mounds. Question marks without grey bars indicate estimates made in the absence of radiocarbon dates. (Plan courtesy of Çatalhöyük Research Project.)

underfloor burials and a rich symbolic tradition observed over much of the approximately 1200 -year sequence of the intensively studied East Mound. Less well known is Çatalhöyük's West Mound, which was the subject of smaller-scale excavations by Mellaart, and more recently (1998-2013) by various other teams. Situated approximately $200 \mathrm{~m}$ from the East Mound (Figure 1) across a former course of the Çarşamba River, Çatalhöyük West has traditionally been viewed as a separate Early Chalcolithic occupation, commencing in the early sixth millennium BC, after the abandonment of the East Mound. Until now, it has been unclear whether there was an intervening hiatus between the occupations of the two mounds. 
Thirty-three newly obtained AMS dates presented here conclusively demonstrate overlap in occupation of the two mounds. Based on these, Çatalhöyük East and West should be seen as a single settlement whose focus of occupation shifted gradually, probably over one or two centuries, around the turn of the seventh to sixth millennia BC. The implications of this extend beyond Çatalhöyük, informing supra-regional models that link late seventh-millennium settlement disruption to rapid climate change, and challenging the conventional notion of prehistoric tell settlements as discrete, bounded entities.

\section{Cultural change at Çatalhöyük}

The Çatalhöyük sequence offers the impression of a continuous, large-scale Neolithic occupation, showing relative cultural and economic stability through the seventh millennium BC, until a rupture marked by disaggregation (e.g. Baird 2005: 69-74) and cessation of occupation on the East Mound-followed by apparently smaller-scale reoccupation on the West Mound during the Early Chalcolithic. Under this model, the absence on the West Mound of many 'classic' Çatalhöyük features—such as underfloor burials, wall paintings and bucrania (cattle skull installations) —along with the proliferation of painted pottery and the appearance of new architectural forms, could be taken as evidence of a major cultural break, perhaps caused by the ' $8200 \mathrm{cal}$ BP rapid climate change event' (see below). The narrative of seventh-millennium stability at Çatalhöyük, however, is called into question by recent research on the East Mound, which has produced evidence for substantial changes after c. $6500 \mathrm{BC}$ (Hodder 2014). Meanwhile, excavations on the West Mound (Gibson \& Last 2003; Biehl et al. 2012) and uppermost East Mound (Marciniak \& Czerniak 2007) have emphasised elements of continuity as well as change.

\section{The East Mound: from continuity to change}

Research at Çatalhöyük East has highlighted compelling evidence for a major shift in social organisation at c. $6500 \mathrm{BC}$ (Hodder 2014), with a decrease in overall population and a shift from an agglomerated settlement structure to a looser arrangement with large gaps between house clusters. Houses became fewer in number but larger in size and of a more complex structure. Households started to manage resources with greater independence, coinciding with the abandonment of house-related practices that are argued to have promoted social cohesion between households (Düring \& Marciniak 2005; Hodder 2013). From this, Hodder (2014: 11) has concluded that social organisation was characterised by egalitarianism throughout the sequence, but that social differentiation, competition and economic specialisation became more pronounced after $6500 \mathrm{BC}$. This heralded a period of ongoing social change, with further significant developments-including the disappearance of underfloor burials_after c. 6300 BC (Marciniak et al. 2015). The East Mound's population continued to decline, with its north eminence probably abandoned by c. $6300 \mathrm{BC}$; by $6000 \mathrm{BC}$, the only known buildings left in use were at the summit of the south eminence (the 'TP' (Team Poznań) area).

The onset of these changes coincided with an abrupt subsistence shift, including the first appearance of hulled barley (Bogaard et al. 2017) and a sharp decline in aurochs and equid hunting, offset by the increased contribution of domestic sheep, goat and the first clearly (C) Antiquity Publications Ltd, 2018 
domesticated cattle (Russell et al. 2013). Herd mortality profiles hint at a shift from pooled herds to household-level management, fitting the broader picture of household autonomy, while stable isotope analysis of animal bones and biomechanical analysis of human bones suggest that mobility in the landscape steadily increased (Hodder 2014; Larsen et al. 2015). The latter, in turn, corresponds with the appearance of smaller, possibly seasonally occupied sites on the Konya Plain, such as Pınarbaşı B (Baird et al. 2011).

\section{The West Mound: from change to continuity?}

Given increasingly clear evidence for dynamism at Çatalhöyük East, could the shift to a new location simply represent one development among many in a time of changing settlement practices, rather than a radical break with the past? By the late seventh millennium BC, occupation had already contracted from both eminences of the East Mound to just the southernmost. The subsequent or concurrent expansion at a third locus a few hundred metres west, albeit across a probable river channel, need not have been a major disruption to local lifeways, especially if gradual.

Continuity between the mounds is supported by new research at Çatalhöyük West (Anvari et al. 2017). Many of the changes in material culture observed at the West Mound can be argued to have roots in the cultural trajectory of the East Mound. These include large, probably two-storey, buildings that can be linked to the rapid architectural changes seen in the TP area, and to further expansion of household autonomy. The distinctive painted pottery is also anticipated in the later East Mound sequence by the presence of new shapes and occasional decorated sherds (Last 2005; Özdöl-Kutlu et al. 2015). Meanwhile, continuity indicated by subsistence data is striking (Russell et al. 2013), and the appearance of additional smaller settlements on the plain after c. 6000 BC (Baird 2005: 71-73) indicates acceleration of the Late Neolithic trend of greater mobility and more extensive landscape use.

\section{Wider significance}

Developments at Çatalhöyük took place within a dramatically changing late seventhmillennium cultural landscape. Following the widespread uptake of farming in Western and North-western Anatolia c. 6500 BC, an increasingly diverse cultural landscape developed in Late Neolithic/Early Chalcolithic Central, Southern and Western Anatolia, with innovations such as painted pottery and new crop and animal husbandry techniques exchanged between regions (Düring 2011: 199, 2013). The 8200 BP climate event has been posited as a cause for various social disruptions in Anatolia and beyond, including the EastWest shift at Çatalhöyük (Weninger et al. 2009: 33-34; Clare \& Weninger 2014; Clare 2016: 178), although its effect on Central/Western Anatolian environments and settlement processes is debated (Asouti 2009; Flohr et al. 2016; Willett et al. 2016; Ayala et al. 2017).

Çatalhöyük is central to these debates, and the shift in occupation is a recurring issue: was it abrupt, gradual or was there a hiatus? As long as the date of the foundation of the West Mound relative to the abandonment of the East Mound remains obscure, there can be no clear understanding of the translocation, what it meant for the community at Çatalhöyük, nor indeed of any relationship to climatic events and wider cultural developments. 
By starting to establish this chronological relationship, the new dates presented here pave the way for the construction of a unified settlement history of Çatalhöyük.

\section{Previous dating at Çatalhöyük}

\section{The East Mound}

Dating has concentrated on the higher southern eminence, where a $21 \mathrm{~m}$ sequence divided into 'levels', XII (earliest) to 0 (latest), by Mellaart (1964), with the later addition of four 'pre-XII' levels (Cessford 2001), probably represents almost the entire duration of occupation. Based on 26 radiocarbon dates from levels XII-II, Mellaart (1978: 13) estimated an occupation of $c .7100-6300 \mathrm{BC}$. While his start date has proved remarkably accurate (Bayliss et al. 2015), subsequent research has pushed the undated final levels steadily towards the end of the seventh millennium: Thissen (2002: 324) suggests 62006100 BC, and Cessford (2005: 77) 6200-5900 BC; the latter taking into account erosion and late dates from a buried soil horizon in the off-site KOPAL excavation area (Table S1).

Recent excavations at the summit of the south eminence (the TP area), adjacent to the sequence detailed above, have finally provided dates for Mellaart's levels I-0 (Marciniak \& Czerniak 2007; Marciniak et al. 2015). Abandonment of the latest-known domestic building (building 33) is now securely dated to 6015-5905 BC at 95\% probability, with an 83 per cent chance that interments continued in a nearby burial chamber (Sp.428) after this point, while cessation of occupation is estimated as $5975-5865 \mathrm{BC}$ at $95 \%$ probability, although two later dates from an overlying midden suggest that sporadic activity continued (Marciniak et al. 2015: 172-73). More limited dating from shallower excavations on the north eminence indicate that it was abandoned by c. 6300 BC (Hodder 2014: 4; see Cessford 2005; Stevanović 2012).

\section{The West Mound}

The West Mound has been the subject of several excavations, albeit much more limited in depth and extent than those on the East Mound. Mellaart's trenches - trench 1 close to the summit, and trench 2 towards the south-western edge (Mellaart 1965)_-were reopened and laterally extended between 1998 and 2003, along with two very small soundings (trenches 3-4) on the eastern peripheries (Last 1998; Gibson \& Last 2003). Three further trenches were excavated between 2006 and 2013: trenches 5-6 towards the top of the mound's eastern 'shoulder', and trench 7 nearby on the mound's easternmost edge (Biehl et al. 2012). Finally, an eighth trench (trench 8) was excavated at the south-west of the mound (Erdoğu 2012).

The chronology of the West Mound has been contested from the outset. With no radiocarbon results available until 2002, estimates were subject to both revisions in the dating of the East Mound and conflicting perceptions of cultural and pottery sequences in wider Central Anatolia. In Mellaart's view, painted pottery dated Çatalhöyük West to the Early Chalcolithic I and II, indicating that it was "occupied after the desertion of the Neolithic site, perhaps from c. 5600 BC [uncalibrated]" (1965: 135), although he also remarked that unexcavated Late Neolithic levels could exist. Following the calibration of the East Mound dates, Mellaart adjusted this to $6300 \mathrm{BC}$, retaining his (never explicitly (C) Antiquity Publications Ltd, 2018 
justified) hypothesis of a seamless transition: "Around $6300 \mathrm{BC}$ the site of Çatal Hüyük was moved across the river, for some reason still unknown to us, and rebuilt as Çatal Hüyük West” (1978: 23). By contrast, French (1967) placed Çatalhöyük West at c. 5650-5500 BC (after calibration), opening up a gap of 650-800 years between the mounds. This hiatus has persisted in the literature, although estimates of length vary: Thissen (2002: 324) tentatively dates Çatalhöyük West to 6000-5600 BC, only slightly post-dating the East Mound in his model, while Schoop (2005: 129-31) argues for a four- to five-century hiatus, dating the West Mound to between 5700 and 5500 BC.

The first radiocarbon dates from the West Mound calibrate to c. 6000-5800 BC (Göktürk et al. 2002; see Table S1). Based on unidentified charcoal, these may be older than their context due to the old wood effect. Conversely, as they were recovered from approximately $250-400 \mathrm{~mm}$ above natural alluvium in a core taken on the southern slope of the mound, they may not represent the earliest anthropogenic deposits, especially given the evidence for substantial colluviation in trenches 3 and 4 (Last 1998). Nonetheless, based on these and the KOPAL dates, Cessford (2005: 95) argues for "only a relatively brief interval between the occupation of the two sites, or possibly no interval at all". Cessford's view has subsequently been supported by the TP dates (see above), although Weninger et al. (2009: 34) maintain that there is a "glaring 200-year gap". Five dates from trench 7, three of which pre-date $5750 \mathrm{BC}$ at $68.2 \%$ (Biehl et al. 2012; Table S1), provide further support for continuity or even overlap between the mounds, but because of stratigraphic inconsistencies, these require reassessment (see below).

In sum, three models have been suggested for the East-West Mound transition at Çatalhöyük, each with different implications for the nature of social change:

1) Mellaart's hypothesis of an abrupt but seamless transition.

2) French's hiatus.

3) An overlap, tentatively raised by Mellaart and recently revisited in response to the first radiocarbon dates from the West Mound and uppermost East Mound (Marciniak \& Czerniak 2007: 123; Düring 2011: 133; Biehl et al. 2012: 59-60).

Of these, recent evidence militates strongly against an appreciable hiatus. The East Mound occupation almost certainly lasted into the first century of the sixth millennium BC (Marciniak et al. 2015), while four West Mound samples_-some of them admittedly problematic-fall between 6100 and $c .5800 \mathrm{BC}$. The question that remains is whether it was an abrupt transition or a gradual shift in occupation over decades or centuries. With the end of the East Mound sequence definitively dated, only the dating of the West Mound requires satisfactory resolution.

\section{Samples and results}

Thirty-three AMS dates on 32 short-life samples (S\# from here on) from Çatalhöyük West are presented here, deriving from trenches 1, 2, 5 and 7 . These relatively shallow excavations (except for trench 7), represent some of the latest occupation in their respective areas and lack the multiple building levels excavated on the East Mound (Figures 2 \& 3). Of 34 samples, 32 produced successful determinations (Tables 1 \& S2). Sixteen samples 

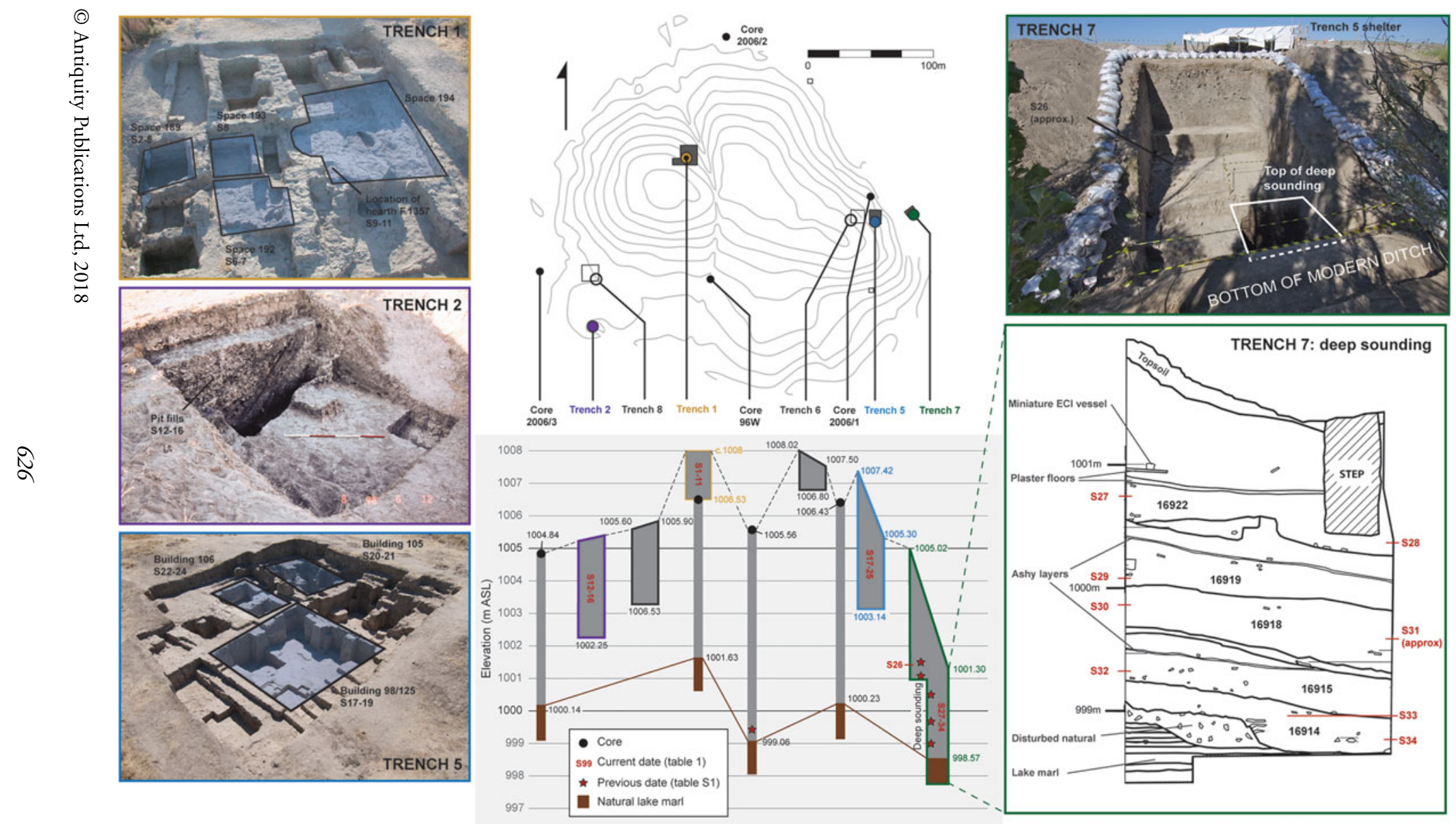

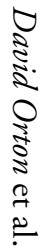

Figure 2. Positions and elevations of interventions at Çatalhöyük West, with details of approximate provenance for dating samples. (Photographs by Jason Quinlan and Peter Biehl. Trench 7 section drawing by Ingmar Franz.) 


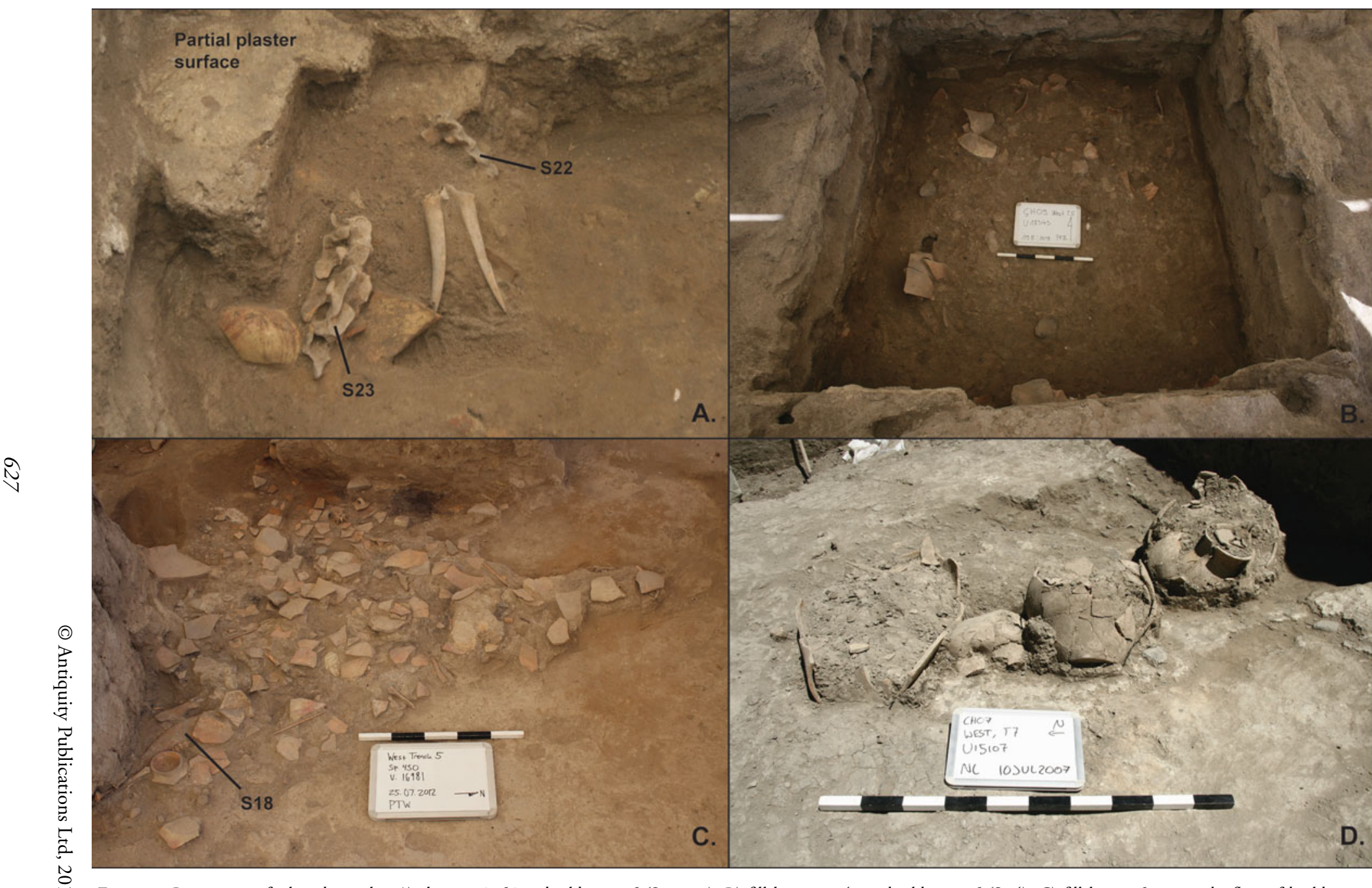

Figure 3. Provenance of selected samples: A) cluster 15365 in building 106 (S22-23); B) fill layer 18343 in building 106 (S24); C) fill layer 16981 on the floor of building 98 (S18); and D) surface 15107 in trench 7 (S26, Poz-24048). (Photographs by Peter Biehl and Patrick Willett.)

Research 
Table 1. New radiocarbon dates from Çatalhöyük West. (See text for calibration details and Table S2 for full contextual information and supporting data.)

\begin{tabular}{|c|c|c|c|c|}
\hline \multirow[b]{2}{*}{ S\# } & \multicolumn{3}{|l|}{ Laboratory number } & \multirow{2}{*}{$\begin{array}{l}\text { Calibrated date } \\
\text { BC }(68.2 \%)\end{array}$} \\
\hline & & Date & s.d. & \\
\hline & Trench 1 & & & \\
\hline 1 & OxA-11759 & 7028 & 39 & $5983-5887$ \\
\hline 2 & OxA-11750 & 7065 & 40 & $5998-5906$ \\
\hline 3 & OxA-12089 & 6990 & 40 & $5975-5816$ \\
\hline 4 & OxA-11757 & 7103 & 39 & $6021-5922$ \\
\hline 5 & OxA-11758 & 7028 & 37 & $5982-5887$ \\
\hline 6 & OxA-11751 & 7070 & 45 & $6004-5906$ \\
\hline 7 & OxA-11755 & 7049 & 39 & $5986-5901$ \\
\hline 8 & OxA-11756 & 6937 & 38 & $5871-5752$ \\
\hline 9 & OxA-11754 & 6945 & 39 & $5877-5771$ \\
\hline 10 & OxA-11773 & 6915 & 34 & $5836-5744$ \\
\hline \multirow[t]{2}{*}{11} & OxA-11774 & 6969 & 36 & $5897-5793$ \\
\hline & Trench 2 & & & \\
\hline 12 & OxA-11760 & 6904 & 39 & $5834-5735$ \\
\hline 13 & OxA-11761 & 6730 & 40 & $5701-5619$ \\
\hline 14 & OxA-11764 & 6707 & 38 & $5661-5570$ \\
\hline 15 & OxA-11762 & 6662 & 38 & $5627-5559$ \\
\hline \multirow[t]{2}{*}{16} & OxA-11763 & 6626 & 36 & $5616-5533$ \\
\hline & Trench 5 & & & \\
\hline 17 & OxA-29613 & 6912 & 36 & $5836-5741$ \\
\hline 18 & OxA-29614 & 6944 & 36 & $5877-5768$ \\
\hline 19 & OxA-29615 & 7007 & 36 & $5976-5846$ \\
\hline 20 & OxA-27744 & 6986 & 36 & $5972-5814$ \\
\hline 21 & OxA-27667 & 7059 & 37 & 5991-5904 \\
\hline 22 & OxA-27665 & 6966 & 37 & $5895-5789$ \\
\hline 23 & OxA-27666 & 6992 & 36 & $5974-5840$ \\
\hline 24 & OxA-27663 & 6918 & 38 & $5837-5746$ \\
\hline 24 (rep.) & OxA-27664 & 6941 & 37 & $5873-5762$ \\
\hline \multirow[t]{2}{*}{25} & OxA-27662 & 6950 & 36 & $5881-5780$ \\
\hline & Trench 7 & & & \\
\hline 26 & SUERC-59349 & 6782 & 34 & $5713-5657$ \\
\hline 27 & OxA-27672 & 7247 & 36 & $6206-6060$ \\
\hline 28 & Insufficient collagen & & & \\
\hline 29 & OxA-27671 & 7013 & 40 & $5979-5846$ \\
\hline 30 & OxA-27670 & 7074 & 36 & $6003-5914$ \\
\hline 31 & SUERC-59350 & 6877 & 32 & $5788-5721$ \\
\hline 32 & OxA-27669 & 7043 & 36 & $5983-5901$ \\
\hline 33 & OxA-27668 & 7205 & 36 & $6085-6018$ \\
\hline 34 & Insufficient collagen & & & \\
\hline
\end{tabular}

from trenches 1 and 2 were published by Higham et al. (2007), but are discussed here in context for the first time. Calibration and modelling used OxCal 4.3 (Bronk Ramsey 2009) and the IntCal13 calibration curve (Reimer et al. 2013). Full OxCal code is provided as supplementary information.

(C) Antiquity Publications Ltd, 2018 


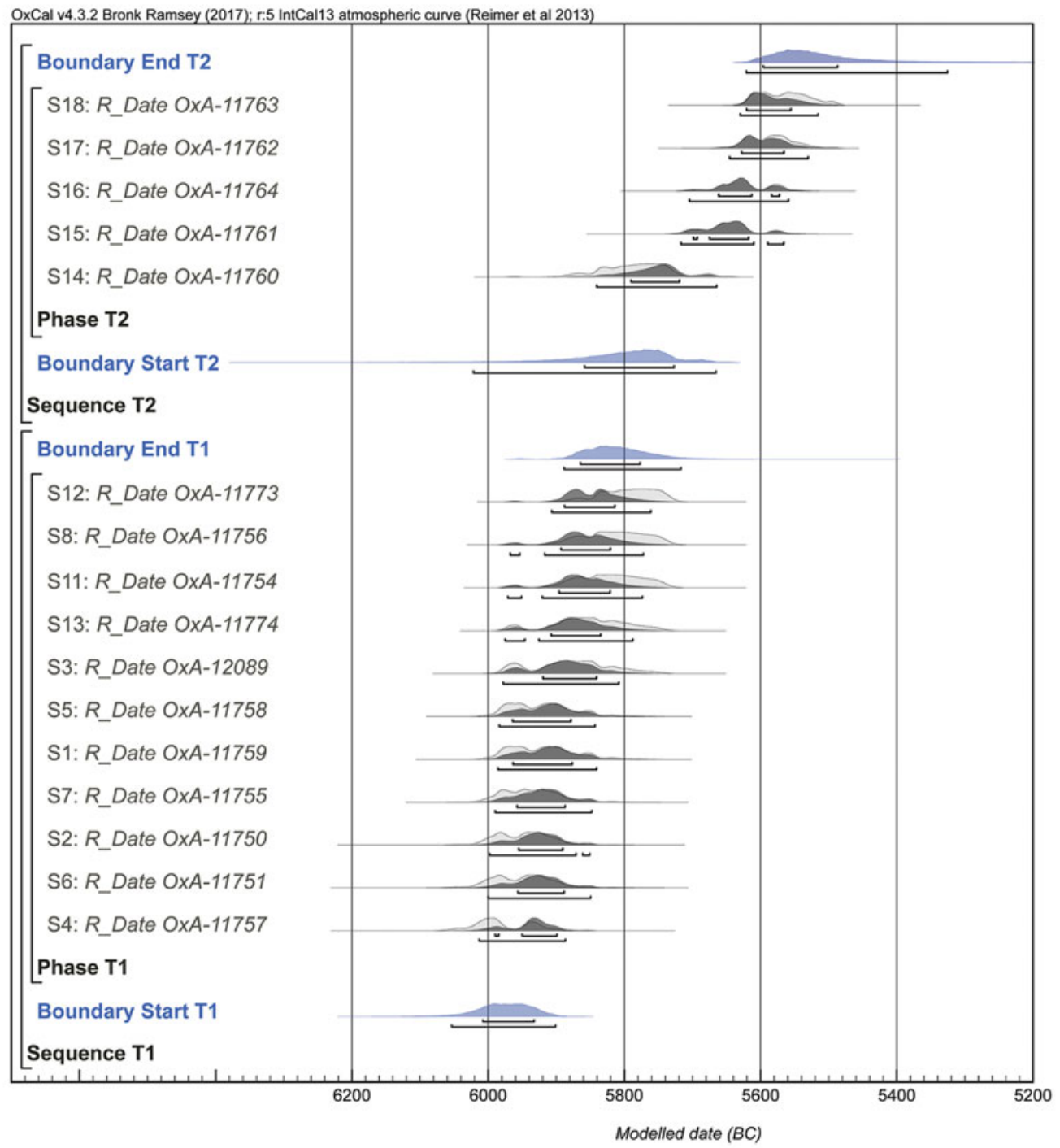

Figure 4. Radiocarbon results from trenches 1-2.

\section{Trench 1}

S1-11 are charred cereal grains from building 25 in trench 1, associated with Early Chalcolithic I pottery and adjacent to deposits excavated by Mellaart. A core taken beneath this building indicates a further $4.9 \mathrm{~m}$ of anthropogenic deposits below the limit of excavation (Gibson et al. 2000).

Treating these as a single phase (Figure 4) gives estimated start and end dates of 6010 5935 BC and 5865-5780 BC respectively at 68.2\% (6055-5900 BC and 5890-5720 BC at 95.4\%) - confirming that the West Mound was occupied during the first quarter of

(C) Antiquity Publications Ltd, 2018 
the seventh millennium BC, possibly as far back as $6000 \mathrm{BC}$, even before unexcavated underlying deposits are taken into account.

\section{Trench 2}

S12-16 are charred cereal grains from two intercutting pits in trench 2, associated with Early Chalcolithic II pottery as noted by Mellaart (1965: 136). These span a surprisingly long period (Figure 4), from 5860-5730 to 5600-5485 BC at 68.2\% (6025-5665 to 56255320 at 95.4\%). Nevertheless, through comparison with building 25, these dates can be seen to confirm Mellaart's relative chronology of Early Chalcolithic I and II.

\section{Trench 5}

S17-25 derive from three Early Chalcolithic I building/infill sequences in trench 5 . Being from in situ articulated bone, these dates are amenable to stratigraphic modelling, albeit limited by shallow stratigraphy and a lack of crosslinks (Figure 5). This gives a tight range with start and end boundaries of 5950-5860 BC and 5840-5760 BC respectively at $68.2 \%$ (6010-5845 and 5875-5710 at 95.4\%). This suggests that occupation commenced by $c$. $5900 \mathrm{BC}$, again not taking into account unexcavated underlying deposits - the deepest sample dated from trench 5, S19, was taken from a level some $3 \mathrm{~m}$ higher than the lowest anthropogenic deposits recorded in a nearby core (2006/1, see Figure 2).

\section{Trench 7}

Trench 7 was cut into the side of a $3.7 \mathrm{~m}$-deep modern irrigation ditch at the south-east edge of the mound, with a small 'deep sounding' continuing through a further, approximately $2.8 \mathrm{~m}$ of cultural deposits to natural lake marl. S26 derives from a surface associated with in situ Early Chalcolithic I pots, towards the base of the main trench, while S27-34 are spread through the deep sounding. Only two articulated bone sets were available for dating (S26 $\& 31$ ), with the other dates taken from disarticulated bone.

Although trench 7 produced five previously published radiocarbon dates (Table S1; Biehl et al. 2012), their chronological order does not fit the stratigraphic sequence. The interface with the natural deposits gave the latest date of 4900-4695 BC at 68.2\% (Poz-24051), while the earliest date of 6058-6005 BC at 68.2\% (Poz-24048) was obtained from the same surface as S26, stratigraphically above the deep sounding. Residuality alone cannot be responsible for this incongruence. If correct, Poz-24051 would make the entire trench 7 sequence post-sixth millennium BC, including several in situ floors with Early Chalcolithic pots. Contamination is more plausible: all five samples have C: $\mathrm{N}$ ratios outside the expected range for collagen of 2.9-3.6 (DeNiro 1985), with Poz-24051 being particularly high (Figure 6). By contrast, all 16 new dates from trenches 5 and 7 fall within the expected range.

The two articulated bone samples provide reliable anchors. Sample 26 places the end point of the dated sequence at 5715-5660 BC (68.2\%), while sample 31, from mid-way through the deep sounding, dates to 5790-5720 BC (Figure 7). The five disarticulated bone samples may be residual, particularly given the tell-edge stratigraphy. This is clear for (C) Antiquity Publications Ltd, 2018 


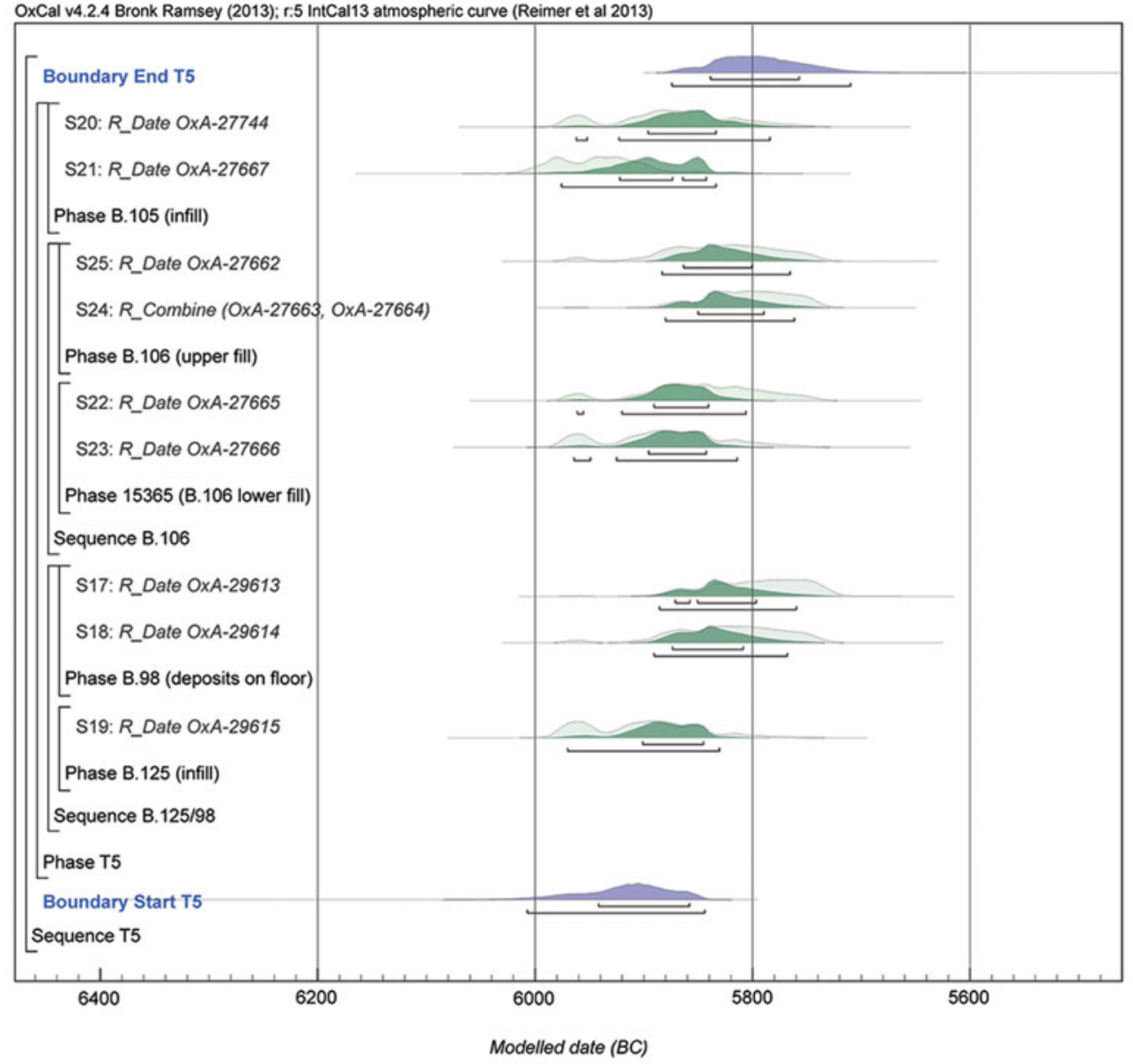

Figure 5. Radiocarbon results from trench 5.

S27-30, stratigraphically between S26 and 31, but significantly pre-dating both. S32-33 from below S31 may or may not be in their original context.

Our model for trench 7 fully includes only the two articulated samples, treating the others as termini post quos (Figure 7) to produce a very uncertain start boundary of 5920 5715 BC (68.2\%). All five of the disarticulated samples pre-date $5800 \mathrm{BC}$, however, with two of five falling in the late seventh millennium BC. These probably represent activity in the broader vicinity, perhaps redeposited through downwash, although we cannot entirely exclude the East Mound as a point of origin.

\section{Overall model}

Each dated trench/core was included within an overall bounded phase representing West Mound occupation. Under this model, occupation is estimated to have lasted between 6015-5965 and 5615-5570 BC at 68.2\% (6040-5935 and 5625-5530 at 95.4\%). 


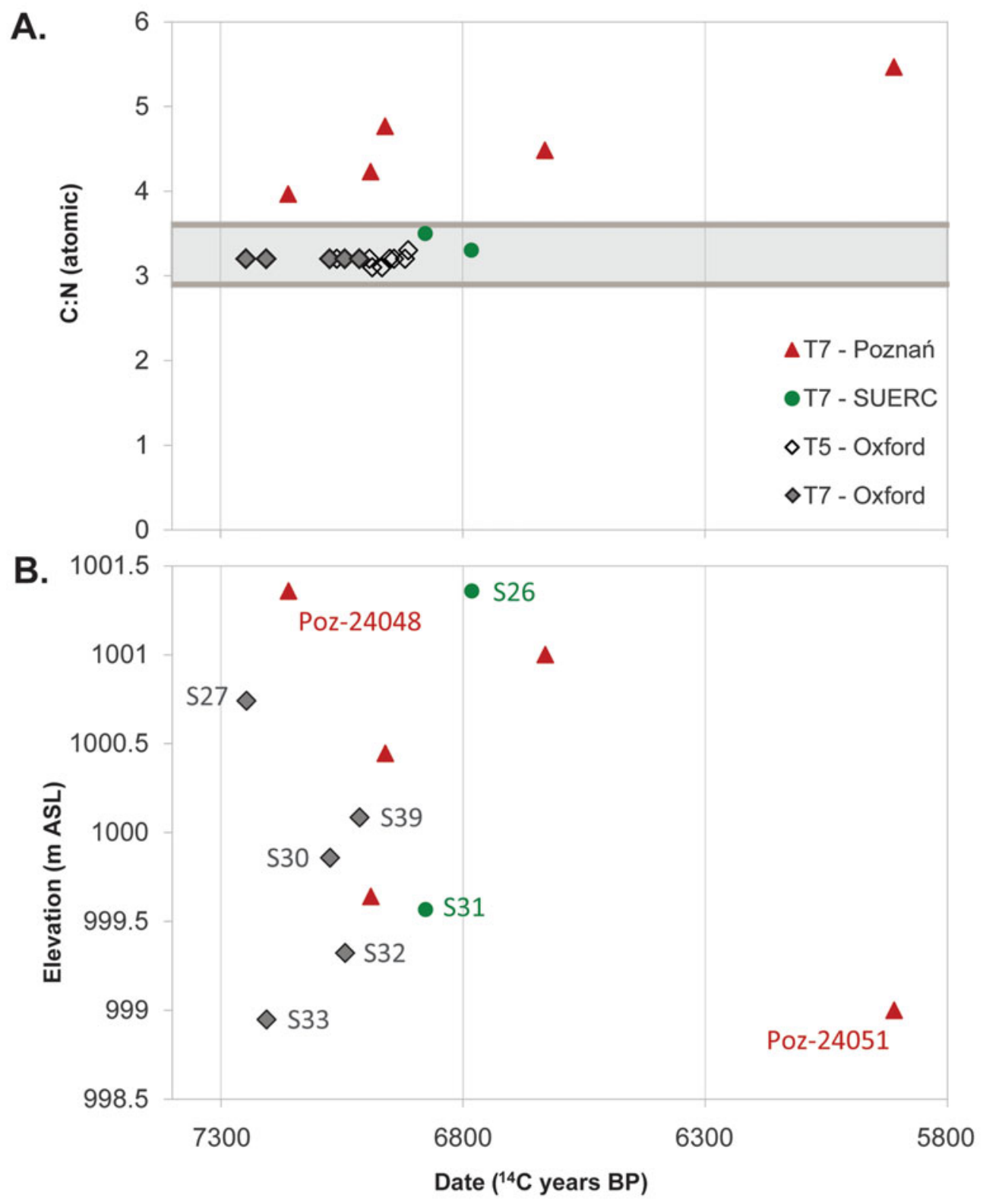

Figure 6. Radiocarbon ages of trench 7 dates against (A) carbon:nitrogen ratio (C:N, grey band shows expected range) and (B) elevation.

This almost certainly underestimates significantly the antiquity of the mound, considering the metres of unexcavated deposits underlying trenches 1 and 5. Nonetheless, Figure 8 compares start boundaries for our overall West Mound model, and each trenchlevel model, with the estimated end dates reported for the East Mound, and more (C) Antiquity Publications Ltd, 2018 


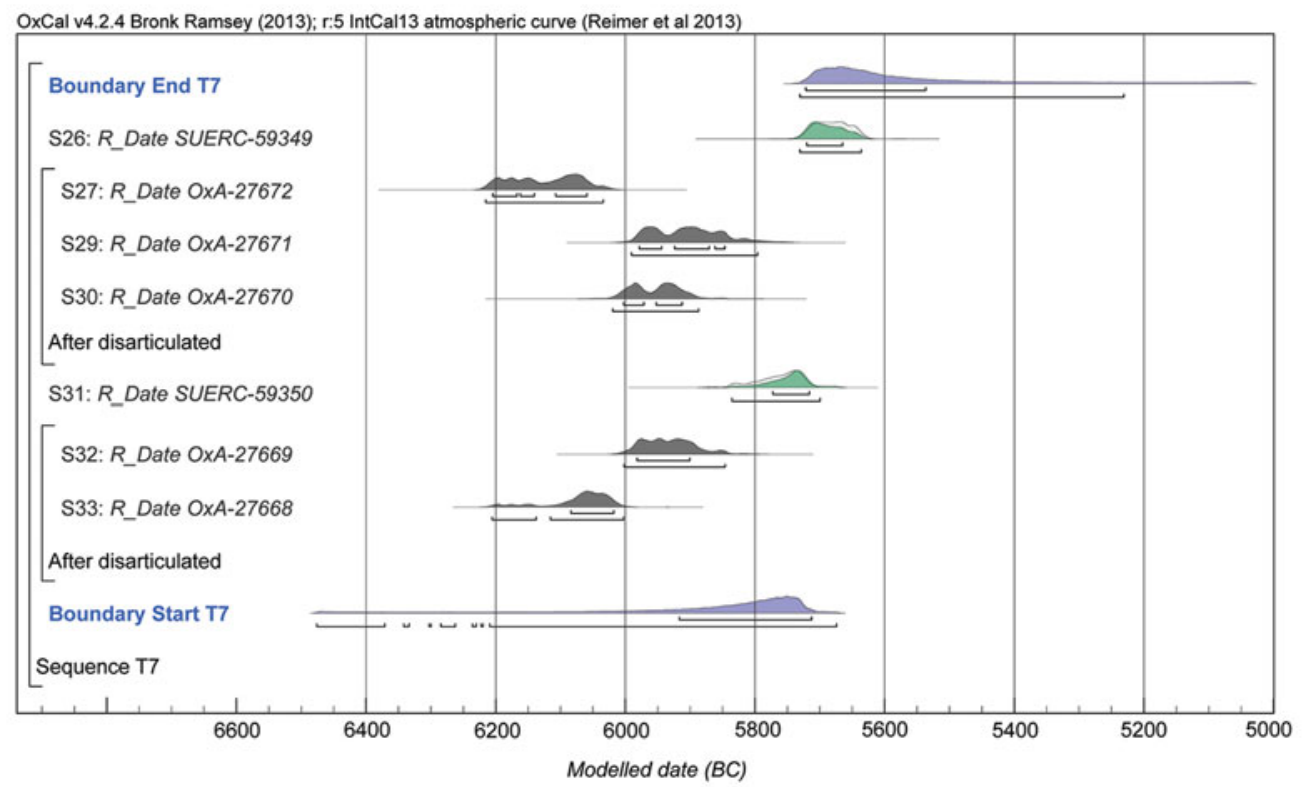

Figure 7. Radiocarbon results from trench 7.

specifically for the final domestic structure (building 33) and burial chamber (Sp.248) respectively (Marciniak et al. 2015: fig. 2).

The impression given is of a clear overlap in activity and probable overlap in occupation. This is confirmed by direct comparison between the start boundary for our overall model and the end boundary for Çatalhöyük East, which, even without factoring in the potential age of the unexcavated deposits, gives an overlap in occupation of 20-100 years at $68.2 \%$ or between 150 years' overlap and 10 years' hiatus at 95.4\% (Figure 9).

\section{Discussion}

Our results confirm that there was no hiatus between settlement on the two mounds. Dates from trenches 1 and, arguably, 7 demonstrate that Çatalhöyük West was occupied by the first century of the sixth millennium BC, while activity at Çatalhöyük East persisted until at least the middle of the same century (Marciniak et al. 2015). A strong case can now be made for a significant overlap between the two tells:

1. Based on 11 AMS determinations, deposits in trench 1 associated with building 25 began at 6010-5935 BC (68.2\%), matching the estimated end date for building 33, the last-known domestic structure on the East Mound. The $4.9 \mathrm{~m}$ of anthropogenic deposits beneath building 25 must represent a significant period of prior activity. While the rate of höyük build-up at Çatalhöyük West is unknown and, as with all tells, probably complex and varied, a crude extrapolation from the overall height and duration of the East Mound would give a very rough estimate of approximately 250 years. 


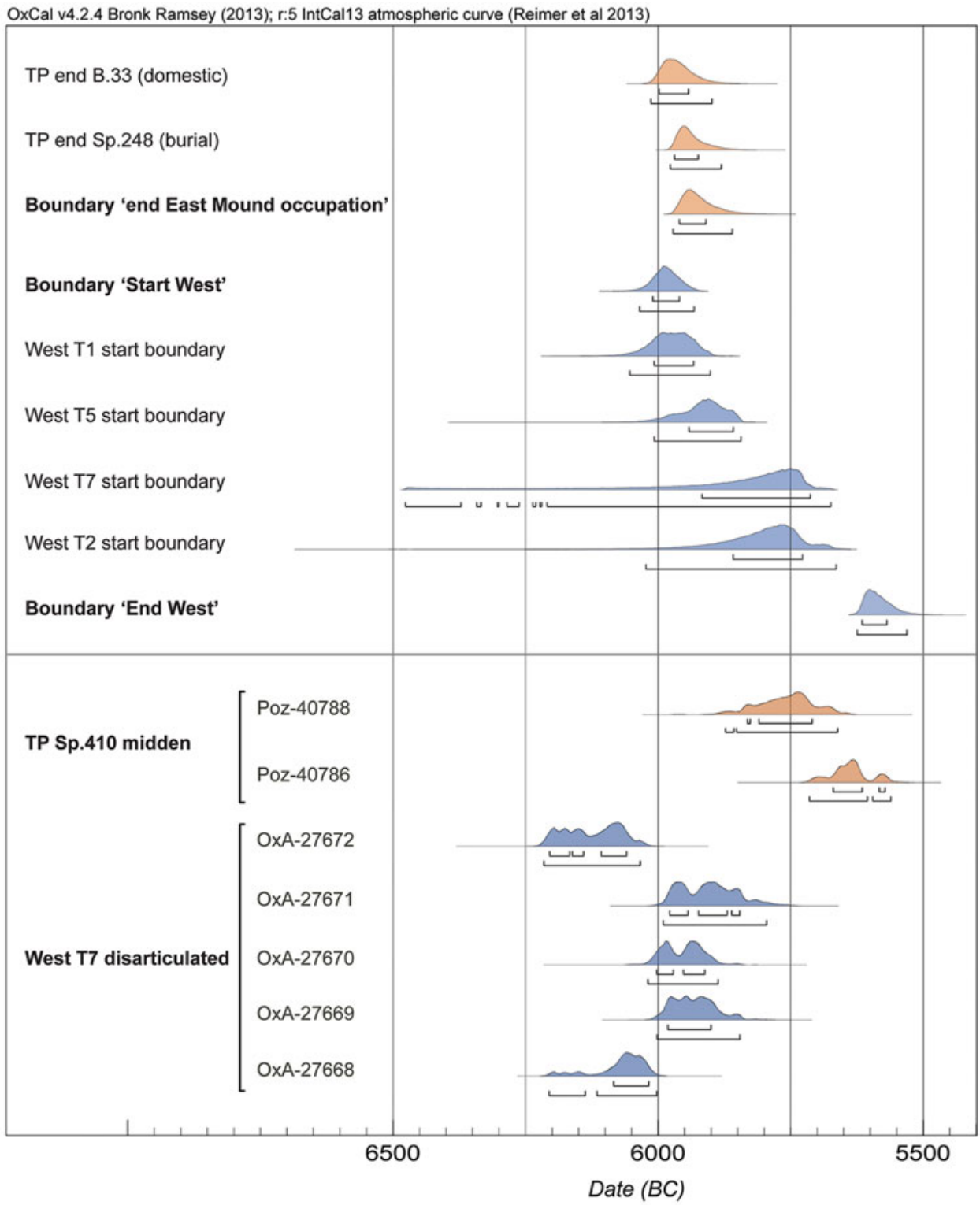

Figure 8. Estimated end dates for Çatalhöyük East (Marciniak et al. 2015), and start and end boundary dates for Çatalhöyük West, plus selected un-modelled dates.

2. Coring near trench 5 indicates an additional, approximately $3 \mathrm{~m}$ of anthropogenic deposits beneath the limit of excavation, again suggesting occupation commenced well before the 5950-5860 BC (68.2\%) estimated here-perhaps around 160 years (calculated using the same method as above).

3. Two of the five disarticulated bone samples from trench 7 date to the late seventh millennium BC, while the remainder date to the first two centuries of the sixth

(C) Antiquity Publications Ltd, 2018 


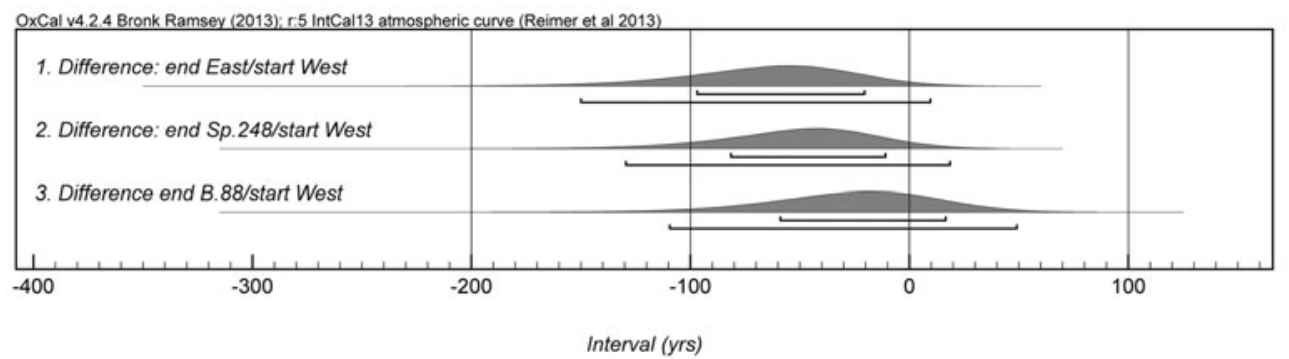

Figure 9. Intervals between estimated start dates for Çatalhöyük West and end dates for: 1) all East Mound occupations; 2) the last burial chamber in the TP area; and 3) the last domestic structure in the TP area. Negative numbers indicate overlap; positive numbers indicate hiatus. This model does not account for unexcavated deposits.

millennium BC. Even if all are residual, their most plausible point of origin is from farther up the mound; it is unlikely that both early samples derived from the East Mound.

Taking these points together, we propose a significant period of co-existence between the two tells, although we cannot reliably estimate its duration without excavation down to the natural sediments in a non-peripheral area of the West Mound. A conservative estimate of c. $6100 \mathrm{BC}$ for the start of occupation implies an overlap of up to two centuries.

Traditionally, the two mounds have been seen as discrete settlements with distinct communities. Viewed as a single settlement, with shifting foci of occupation, their coexistence does not require special explanation. Settlement on the East Mound had already shifted over time with the abandonment of the north eminence during the later seventh millennium BC. A gradual transition from East-West Mounds seems a priori more probable than a sudden translocation of the entire community, although it remains unclear why settlement shifted when it did. Explanations linked to changes in river course and/or water regime (Roberts \& Rosen 2009: 399) may still apply, with some residents moving closer to the water supply, while others chose to remain in the traditional settlement core. Alternatively, or additionally, the expansion might represent social fissioning, linked to the increased household autonomy, competition and mobility posited for the later seventh millennium.

Despite evidence for an Early Chalcolithic population dispersal on the Konya Plain (Baird 2005: 71), the East-West transition at Çatalhöyük need not have entailed a reduction in population. Although the West Mound's footprint is smaller than that of the East, the latter's population had already declined significantly by the later seventh millennium BC (Hodder 2014: 12). The extent to which this was balanced by expansion to the West Mound depends partly on the as yet unknown chronological relationship between the foundation of the West Mound and the abandonment of the north eminence of the East Mound. We cannot assume that the population of Çatalhöyük West was, at its height, smaller than that of late seventh-millennium Çatalhöyük East.

The early dating of trenches 1 and 5 indicates either that the most visible material changes between Çatalhöyük East and West were rapid, with roots in the later East Mound sequence, or that their development represented a divergence in practices. Dated deposits in trenches 
1,2 and 5 are characterised by abundant painted pottery, pushing this development back to the second, if not the first, century of the sixth millennium BC, while buttressed two-storey buildings are present in trench 5, at least, by c. $5900 \mathrm{BC}$.

That Çatalhöyük East and West were a single settlement does not preclude some degree of social differentiation between them. Decisions about relocation were probably bound up with status, identity and kinship, and there are also hints of functional differentiation. While burial played a central role in the TP area after $c .6200 \mathrm{BC}$, no prehistoric adult burials are yet known from the West Mound. Interments in burial chambers on the East Mound probably continued for "a few decades" (Marciniak et al. 2015: 154) after the cessation of settlement activity, with the implication that those interred-and those who interred them-were residents of Çatalhöyük West. This may equally apply to some earlier burials. As the focus of occupation shifted to the West Mound, burial, and perhaps other ritual activities, may have remained tied to the traditional settlement core. On the other hand, domestic activity also persisted on the East Mound, almost until its final abandonment. Indeed, two midden dates indicate sporadic activity even after this point (Marciniak et al. 2015: 173). The burial places of Çatalhöyük residents after $c .5900$ BC remain unknown.

Despite significant, rapid change in material culture, there was no sudden disjuncture in settlement at Çatalhöyük, no radical break in the sequence and no need to invoke models entailing external disruption. Instead, reasons for the move may lie in internal processes, with roots in a mid seventh-millennium BC shift in social organisation (Hodder 2014). Environmental stimuli, cultural contacts and population movements might have contributed to these processes, and a gradual settlement shift starting in the late seventh millennium actually accommodates models involving the $8200 \mathrm{BP}$ climate event better than would a sudden move around 6000 BC (Clare 2016; cf. Flohr et al. 2016: 35). Nonetheless, suggestions that climate change caused an abrupt temporary abandonment of the settlement are no longer tenable.

\section{Conclusions}

The East and West Mounds at Çatalhöyük had an appreciable overlap in occupation around $6000 \mathrm{BC}$, although the exact duration remains undetermined. They should thus be seen as parts of a single settlement, with a gradual shift probably beginning within the latter quarter of the seventh millennium BC, and persisting until the first century of the sixth. While the reasons for this shift remain debatable, its gradual nature has two key implications for models of change at Çatalhöyük, and in Central Anatolia more widely.

First, it calls into question the idea that the total population at Çatalhöyük declined rapidly through the later seventh millennium and into the sixth, in association with settlement dispersal on the Konya Plain and beyond. While the East Mound population certainly declined after $c .6500 \mathrm{BC}$, it remains to be seen from what point, and to what extent, this was offset by settlement at Çatalhöyük West. Second, it militates strongly against arguments for a radical disruption to settlement, whether caused by climatic change or population movements. The rate of social change at Çatalhöyük, as in Anatolia more widely, was rapid in the later seventh and early sixth millennia BC, but the continuity (C) Antiquity Publications Ltd, 2018 
between the two mounds suggests that this story is primarily one of fast-paced internal evolution. Ultimately, our findings present a cautionary tale regarding the assumption that prehistoric settlements are coterminous with their visible manifestations, particularly in the form of tells.

\section{Acknowledgements}

We thank the Çatalhöyük Research Project; the Ministry of Culture and Tourism of the Republic of Turkey; the University at Buffalo; Freie Universität Berlin; the Alexander von Humboldt Foundation; the University of Cambridge; the British Academy; several private donors; and numerous colleagues who have contributed to West Mound excavations. We are very grateful to Craig Cessford, who undertook the dating for trenches 1 and 2, funded by NERC. Particular thanks also go to Chris Doherty, Camilla Mazzucato and Alex Bayliss. Dates from trenches 5 and 7 were funded by the NERC Radiocarbon Facility (NF/2012/2/10;AB/DO) and the University of York. Useful comments on drafts were provided by Clive Orton, Tom Higham and Penny Bickle.

\section{Supplementary material}

To view supplementary material for this article, please visit https://doi.org/10.15184/aqy. 2018.91

\section{References}

Anvari, J., J. Brady, I. Franz, G. Naumov, D. Orton, S. Ostaptchouk, E. Stroud, P. Willett, E. Rosenstock \& P. Biehl. 2017. The Çatalhöyük West Mound and the Early Chalcolithic in Central Anatolia, in S.R. Steadman \& G. McMahon (ed.) The archaeology of Anatolia: recent discoveries: 6-39. Newcastle upon Tyne: Cambridge Scholars Publishing.

Asouti, E. 2009. The relationship between Early Holocene climate change and Neolithic settlement in Central Anatolia, Turkey: current issues and prospects for future research. Documenta Praehistorica 36: 1-5. https://doi.org/10.4312/dp.36.1

Ayala, G., J. Wainwright, J. Walker, R. Hodara, J. Lloyd, M. Leng \& C. Doherty. 2017. Palaeoenvironmental reconstruction of the alluvial landscape of Neolithic Çatalhöyük, central southern Turkey: the implications for early agriculture and responses to environmental change. Journal of Archaeological Science 87: 30-43. https://doi.org/10.1016/j.jas.2017.09.002

BAIRD, D. 2005. The history of settlement and social landscapes in the Early Holocene in the Çatalhöyük area, in I. Hodder (ed.) Çatalhöyük perspectives: reports from the 1995-1999 seasons: 55-74. Cambridge: McDonald Institute.

Baird, D., D. Carruthers, A. Fairbairn \& J. Pearson. 2011. Ritual in the landscape: evidence from Pınarbaşı in the seventh-millennium cal BC Konya Plain. Antiquity 84: 380-94. https://doi.org/10.1017/S0003598X0006782X
Bayliss, A., F. Brock, S. Farid, I. Hodder, J. Southon \& R.E. TaYlor. 2015. Getting to the bottom of it all: a Bayesian approach to dating the start of Çatalhöyük. Journal of World Prehistory 28: 1-26. https://doi.org/10.1007/s10963-015-9083-7

Biehl, P.F., I. Franz, D.C. Orton, S. Ostaptchouck, J. Rogasch \& E. Rosenstock. 2012. One community and two tells: the phenomenon of relocating tell settlements at the turn of the $7^{\text {th }}$ and the $6^{\text {th }}$ millennia in Central Anatolia, in R. Hofmann, F.-K. Moetz \& J. Müller (ed.) Tells: social and environmental space: 53-65. Bonn: Habelt.

Bogaard, A., D. Filipović, M. Charles, A. Fairbairn, L. Green, D.Q. Fuller $\&$ E. Stroud. 2017. Agricultural innovation and resilience in a long-lived early farming community: the 1500-year sequence at Neolithic-Early Chalcolithic Çatalhöyük, Central Anatolia. Anatolian Studies 67: 1-28. https://doi.org/10.1017/S0066154617000072

Bronk Ramsey, C. 2009. Bayesian analysis of radiocarbon dates. Radiocarbon 51: 337-60. https://doi.org/10.1017/S0033822200033865

Cessford, C. 2001. A new dating sequence for Çatalhöyük. Antiquity 75: 717-25. https://doi.org/10.1017/S0003598X00089225

- 2005. Absolute dating at Çatalhöyük, in I. Hodder (ed.) Changing materialities at Çatalhöyük: reports from the 1995-1999 seasons: 65-100. Cambridge: McDonald Institute. 
Clare, L. 2016. Culture change and continuity in the Eastern Mediterranean during rapid climate change. Rahden: Leidorf.

Clare, L. \& B. Weninger. 2014. Absolute chronology and rapid climate change in Central and West Anatolia, in M. Özdoğan, N. Başgelen \& P. Kuniholm (ed.) The Neolithic in Turkey volume 6: 1-65. Istanbul: Arkeoloji ve Sanat Yayınları.

DeNiro, M.J. 1985. Post-mortem preservation and alteration of in vivo bone collagen isotope ratios in relation to paleodietary reconstruction. Nature 317: 806-809. https://doi.org/10.1038/317806a0

DüRING, B.S. 2011. The prehistory of Asia Minor. New York: Cambridge University Press.

- 2013. Breaking the bond: investigating the Neolithic expansion in Asia Minor in the seventh millennium BC. Journal of World Prehistory 26: 75-100. https://doi.org/10.1007/s10963-013-9065-6

DürIng, B.S. \& A. MarCiniaK 2005. Households and communities in the central Anatolian Neolithic. Archaeological Dialogues 12: 165-87. https://doi.org/10.1017/S138020380600170X

ErdoĞu, B. 2012. West Mound trench 8. Çatalhöyük Archive Report 2012: 103-104.

Flohr, P., D. Fleitmann, R. Matthews, W. Matthews \& S. Black. 2016. Evidence of resilience to past climate change in Southwest Asia: early farming communities and the 9.2 and $8.2 \mathrm{ka}$ events. Quaternary Science Reviews 136: 23-39. https://doi.org/10.1016/j.quascirev.2015.06.022

French, D. 1967. Excavations at Can Hasan: sixth preliminary report, 1966. Anatolian Studies 17: 105-78. https://doi.org/10.2307/3642446

Gibson, C. \& J. Last. 2003. An Early Chalcolithic building on the West Mound at Çatalhöyük. Anatolian Archaeology 9: 12-14.

Gibson, C., N. Hamilton \& J. Last. 2000. Excavations at Çatalhöyük West. Çatalhöyük Archive Report 2000. Cambridge: Çatalhöyük Research Project.

GöKtürk, E.H., D.J. Hillegonds, M.E. Lipschutz \& I. Hodder. 2002. Accelerator mass spectrometry dating at Çatalhöyük. Radiochimica Acta 90: 407-10. https://doi.org/10.1524/ract.2002.90.7_2002.407

Higham, T., C. Bronk Ramsey, F. Brock, D. Baker \& R. Ditchfield. 2007. Oxford AMS system: archaeometry datelist 32. Archaeometry 49: 1-60. https://doi.org/10.1111/j.14754754.2007.00363.x

Hodder, I. 2013. Dwelling at Çatalhöyük, in I. Hodder (ed.) Humans and landscapes of Çatalhöyük: reports from the 2000-2008 seasons: 1-30. Los Angeles (CA): Cotsen Institute.
- 2014. Çatalhöyük: the leopard changes its spots. A summary of recent work. Anatolian Studies 64: $1-22$. https://doi.org/10.1017/S0066154614000027

Larsen, C.S., S.W. Hillson, B. Boz, M.A. Pilloud, J.W. Sadvari, S.C. Agarwal, B. Glencross, P. Beauchesne, J. Pearson, C.B. Ruff, E.M. Garofalo, L.D. Hager, S.D. Haddow \& C.J. KNÜSEL. 2015. Bioarchaeology of Neolithic Çatalhöyük: lives and lifestyles of an early farming society in transition. Journal of World Prehistory 28: 27-68. https://doi.org/10.1007/s10963-015-9084-6

LAST, J. 1998. Excavations on the West Mound at Çatalhöyük 1998. Çatalhöyük Archive Report 1998. Cambridge: Çatalhöyük Research Project.

- 2005. Pottery from the East Mound, in I. Hodder (ed.) Changing materialities at Çatalhöyük: reports from the 1995-1999 seasons: 101-38. Cambridge: McDonald Institute.

Marciniak, A. \& L. Czerniak. 2007. Social transformations in the Late Neolithic and the Early Chalcolithic periods in Central Anatolia. Anatolian Studies 57: 115-30. https://doi.org/10.1017/S0066154600008541

MarciniaK, A., M. Barański, A. Bayliss, L. Czerniak, T. Goslar, J. Southon \& R.E. TaYlor. 2015. Fragmenting times: interpreting a Bayesian chronology for the Late Neolithic occupation of Çatalhöyük East, Turkey. Antiquity 89: 154-76. https://doi.org/10.15184/aqy.2014.33

MellaArt, J. 1964. Excavations at Çatal Hüyük, 1962 : second preliminary report. Anatolian Studies 14: 39-119. https://doi.org/10.2307/3642466

- 1965. Çatal Hüyük West. Anatolian Studies 15: 135-56. https://doi.org/10.2307/3642506

- 1978. The archaeology of ancient Turkey. Totowa: Rowman \& Littlefield.

Özdöl-Kutlu, S., T. Carter, L. Czerniak \& A. Marciniak. 2015. The end of the Neolithic settlement: Çatalhöyük and its neighbours, in I. Hodder \& A. Marciniak (ed.) Assembling Çatalhöyük: 179-95. Leeds: Maney.

Reimer, P.J., E. BARD, A. BaYliss, J.W. Beck, P.G. Blackwell, C. Bronk Ramsey, C.E. Buck, H. Cheng, R.L. Edwards, M. Friedrich, P.M. Grootes, T.P. Guilderson, H. Haflidason, I. Hajdas, C. Hatté, T.J. Heaton, D.L. Hoffmann, A.G. Hogg, K.A. Hughen, K.F. Kaiser, B. Kromer, S.W. Manning, M. Niu, R.W. Reimer, D.A. Richards, E.M. Scott, J.R. Southon, R.A. Staff, C.S.M. Turney $\&$ J. VAN DER Plicht. 2013. IntCal13 and Marine13 radiocarbon age calibration curves $0-50,000$ years cal BP. Radiocarbon 55: 1869-87. https://doi.org/10.2458/azu_js_rc.55.16947 


\section{A tale of two tells}

Roberts, N. \& A. Rosen. 2009. Diversity and complexity in early farming communities of Southwest Asia: new insights into the economic and environmental basis of Neolithic Çatalhöyük. Current Anthropology 50: 393-402. https://doi.org/10.1086/598606

Russell, N., K.C. Twiss, D.C. Orton \& G.A. Demirergi. 2013. Changing animal use at Neolithic Çatalhöyük, Turkey, in B. De Cupere, V. Linseele \& S. Hamilton-Dyer (ed.) Archaeozoology of the Near East 10: 45-68. Leuven: Peeters.

Schoop, U.D. 2005. Das Anatolische Chalkolithikum. Remshalden: Greiner.

Stevanović, M. 2012. Summary of the results of the excavation in the BACH area, in R. Tringham \& M. Stevanović (ed.) Last house on the hill: $B A C H$ area reports from Çatalhöyük, Turkey: 49-80. Los Angeles (CA): Cotsen Institute.

Thissen, L. 2002. Appendix I: the CANeW ${ }^{14} \mathrm{C}$ database, Anatolia 10,000-5000 cal BC, in F. Gérard \& L. Thissen (ed.) The Neolithic of Central Anatolia: 299-337. Istanbul: Ege Yayınları.
Weninger, B., L. Clare, E.J. Rohling, O. Bar-Yosef, U. Böhner, M. Budja, M. Bundschuh,

A. Feurdean, H.-G. Gebel, O. Jöris, J. Linstädter, P. Mayewski, T. Mühlenbruch, A. Reingruber, G. Rollefson, D. Schyle,

L. Thissen, H. Todorova \& C. Zielhofer. 2009. The impact of rapid climate change on prehistoric societies during the Holocene in the Eastern Mediterranean. Documenta Praehistorica 36: 7-59. https://doi.org/10.4312/dp.36.2

Willett, P.T., I. Franz, C. Kabukcu, D.C. Orton, J. Rogasch, E. Stroud, E. Rosenstock $\&$ P.F. BIEHL. 2016. The aftermath of the 8.2 event: cultural and environmental effects in the Anatolian Late Neolithic and Early Chalcolithic, in P.F. Biehl \& O.P. Nieuwenhuyse (ed.) Climate and cultural change in prehistoric Europe and the Near East: 95-115. Albany (NY): SUNY.

Received: 10 June 2017; Revised: 1 November 2017; Accepted: 6 December 2017 